\title{
PERBEDAAN SOSIAL EKONOMI DAN PENGETAHUAN GIZI IBU BALITA GIZI KURANG DAN GIZI NORMAL
}

\author{
Amelinda Calida Rahma ${ }^{1}$, Siti Rahayu Nadhiroh ${ }^{2}$ \\ 1,2Departemen Gizi Kesehatan, Fakultas Kesehatan Masyarakat, Universitas Airlangga \\ Kampus C Unair Jalan Mulyorejo Surabaya \\ Email: amelinda.calida-12@fkm.unair.ac.id
}

\begin{abstract}
ABSTRAK
Masalah gizi merupakan masalah yang umum terjadi di beberapa negara berkembang termasuk Indonesia. Salah satu faktor yang mempengaruhi status gizi balita adalah pengetahuan gizi ibu yang dipraktikkan dalam pola asuh dan pemberian makan. Kejadian balita gizi kurang juga dipengaruhi oleh faktor sosial ekonomi yang meliputi pendidikan, pekerjaan, pendapatan keluarga, serta pengeluaran pangan. Penelitian ini dilakukan untuk mempelajari perbedaan sosial ekonomi dan pengetahuan gizi ibu balita gizi kurang dan gizi normal. Penelitian ini merupakan penelitian observasional dengan rancangan cross sectional. Sampel dalam penelitian ini adalah balita berusia 24-60 bulan yang berada di Wilayah Kerja Puskesmas Sidotopo, Kota Surabaya. Jumlah sampel penelitian sebesar 19 balita tiap kelompok yang dipilih secara simple random sampling. Pengambilan data menggunakan metode wawancara dengan kuesioner. Hasil penelitian menunjukkan ada perbedaan tingkat pengetahuan gizi ibu $(\mathrm{p}=0,004)$ pada balita gizi kurang dan gizi normal. Tidak terdapat perbedaan pendidikan ibu $(p=0,189)$, pekerjaan ibu $(p=0,387)$, pendapatan keluarga $(p=0,189)$, dan pengeluaran konsumsi $(\mathrm{p}=0,515)$ antara balita gizi kurang dan gizi normal. Kesimpulan dari penelitian ini adalah terdapat perbedaan tingkat pengetahuan gizi ibu balita gizi kurang dan gizi normal tetapi tidak ditemukan perbedaan sosial ekonomi pada kedua kelompok. Oleh karena itu, perlu adanya peningkatan pengetahuan gizi dan keterampilan ibu melalui pelatihan.
\end{abstract}

Kata kunci: balita, pengetahuan gizi, status gizi

\begin{abstract}
There are many malnutrition problems in children under five, especially in developing countries including Indonesia. One of factor affecting nutritional status is maternal nutrition knowledge that will imply in caring and feeding practice. Underweight is also affected by social economy factors such as family income, food expenditure, mother's education and occupation. Therefore, the aim of this research was to analyze differences of social economy characteristic and maternal nutrition knowledge between under-five children with underweight and normal nutritional status. This research was analytical-observational study with cross sectional design. Sample of this research was children aged 24-60 months that living in the working area of Sidotopo Public Health Centre. The number of sample was 19 children in each sub-population based on nutritional status. Data was collected through primary data collecting with direct interview and questionnaire. The result showed significant difference of maternal nutrition knowledge between children with underweight and normal nutritional status $(p=0.004)$. There is no difference in social economy characteristic such as mother's education ( $p=0.189)$, mother's occupation $(p=0.387)$, and family income $(p=0.189)$, and food expenditure $(p=0.515)$. Therefore, improving maternal nutrition knowledge and skills in local community or public health centre is necessary.
\end{abstract}

Keywords: under-five children, nutrition knowledge, nutritional status

\section{PENDAHULUAN}

Status gizi balita menjadi salah satu indikator untuk menilai kesejahteraan masyarakat. Kondisi status gizi balita dapat memprediksi bagaimana output SDM di masa mendatang. Untuk menjadi calon penerus dalam membangun bangsa yang unggul dibutuhkan status gizi yang baik. Menurut Black, et al. (2013), masalah gizi yang sering menjadi penyebab kematian balita adalah masalah kurang gizi.

Status gizi kurang berdampak pada balita di masa mendatang. Oleh karena itu, gizi buruk merupakan masalah yang menjadi perhatian karena tidak hanya berdampak pada jangka pendek seperti kerentanan balita terhadap penyakit infeksi, kemampuan bertahan hidup yang rendah, 
IQ rendah, kemampuan kognitif rendah dan juga kematian tetapi juga berdampak pada jangka panjang yaitu memengaruhi kecerdasan calon generasi penerus, serta kualitas dan produktivitas sumber daya manusia (Pelletier dan Frongillo, 2013).

Sebesar $45 \%$ kematian balita dikarenakan kekurangan gizi (Black, et al., 2013). Di Indonesia, istilah gangguan gizi yang lebih sering dipakai pada balita adalah gizi buruk dan gizi kurang.

Prevalensi gizi buruk dan gizi kurang di Indonesia pada tahun 2013 sebesar 19,6\%, terdiri dari $5,7 \%$ gizi buruk dan $13,9 \%$ gizi kurang. Terjadi perubahan prevalensi yang ditunjukkan pada prevalensi gizi buruk yaitu dari 5,4\% pada tahun $2007,4,9 \%$ pada tahun 2010 , dan $5,7 \%$ tahun 2013. Begitu pula dengan prevalensi gizi kurang yang naik sebesar 0,9\% dari 2007 dan 2013 sedangkan dari tahun 2007 ke 2010 tetap dalam angka 13\% (Balitbangkes, 2013).

Berdasarkan hasil survei Penilaian Status Gizi (PSG) dan Profil Kesehatan Kota Surabaya tahun 2014, Puskesmas Sidotopo memiliki jumlah balita yang berstatus gizi kurang berdasarkan indikator BB/U tertinggi pada tahun 2014 yaitu sebesar 21,6\%. Pada tahun 2015, hasil pemantauan status gizi balita di Puskesmas Sidotopo menunjukkan peningkatan untuk persentase balita dengan berat badan sangat kurang dari 1,6\% menjadi 4,4\% (Dinkes Kota Surabaya, 2015).

Masalah gizi tidak terlepas dari masalah makanan karena masalah gizi timbul sebagai akibat kekurangan atau kelebihan kandungan zat gizi dalam makanan. Masalah gizi pada balita menjadi masalah yang penting untuk segera ditangani.

Peran ibu sebagai pengasuh sangat penting dan berpengaruh besar terhadap pertumbuhan balita. Pengetahuan gizi ibu menjadi salah satu faktor yang dapat mempengaruhi status gizi balita. Pengetahuan gizi ibu berkaitan erat dengan praktik pemberian makan balita. Pengetahuan gizi ibu dapat berpengaruh pada sikap dan perilaku dalam pemilihan makan balita (Diana, 2006).

Hasil penelitian oleh Ningsih, et al. (2015), menunjukkan balita dengan pengetahuan gizi ibu yang kurang memiliki hubungan yang bermakna dengan kasus balita gizi kurang. Balita yang tingkat pengetahuan gizi ibunya kurang, berisiko mengalami gizi buruk 5,091 kali lebih besar daripada balita yang ibunya memiliki tingkat pengetahuan baik.

Selain itu, faktor sosial ekonomi yang meliputi tingkat pendidikan dan jenis pekerjaan serta pendapatan dapat mempengaruhi bentuk pola asuh ibu dan pengetahuan gizi yang pada akhirnya mempengaruhi status gizi balita. Di berbagai belahan dunia, terutama negara berkembang, kemiskinan menjadi penyebab dasar masalah gizi. Sosial ekonomi umumnya relatif mudah diukur dan memiliki pengaruh pada konsumsi pangan rumah tangga yang berdampak pada status gizi anggota keluarga terutama balita (Riyadi, et al., 2006).

Penelitian ini bertujuan untuk mempelajari perbedaan karakteristik sosial ekonomi dan pengetahuan gizi ibu antara balita gizi kurang dan gizi normal di Wilayah Kerja Puskesmas Sidotopo, Kota Surabaya.

\section{METODE}

Penelitian ini merupakan penelitian observasional analitik dengan desain penelitian cross sectional. Populasi penelitian ini adalah seluruh rumah tangga yang memiliki balita berusia 24-60 bulan di Wilayah Kerja Puskesmas Sidotopo, Kecamatan Semampir, Kota Surabaya. Sampel penelitian adalah balita berusia 24-60 bulan yang berada di Wilayah Kerja Puskesmas Sidotopo dan telah dilakukan screening status gizi. Kriteria inklusi antara lain tidak sedang sakit dan tidak cacat bawaan serta diasuh oleh ibu kandungnya. Terdapat dua kelompok sampel yang diambil dari dua kelompok sub-populasi yaitu balita dengan status gizi kurang dan kelompok balita dengan status gizi normal berdasarkan indikator $\mathrm{BB} / \mathrm{U}$. Unit penelitian ini adalah balita sedangkan ibu balita sebagai responden penelitian.

Menurut perhitungan rumus sampel minimal untuk dua populasi berdasarkan proporsi, maka didapatkan jumlah sampel minimal di tiap kelompok untuk balita gizi normal dan gizi kurang adalah masing-masing sebesar 19 balita, sehingga total jumlah sampel yang diambil dalam penelitian adalah sebesar 38 balita. Teknik pengambilan sampel dilakukan secara acak dengan menggunakan metode simple random sampling. 
Pengambilan data primer dilakukan dengan wawancara menggunakan kuisioner serta pengukuran antropometri balita untuk berat badan dan tinggi badan menggunakan timbangan digital dan microtoise. Pengumpulan data sekunder tentang data balita dan status gizi diperoleh dari instansi terkait seperti Dinas Kesehatan Kota Surabaya dan Puskesmas Sidotopo.

Penyajian hasil data univariat ditampilkan dalam bentuk deskriptif dengan tabel frekuensi. Data diuji secara statistik menggunakan uji ChiSquare untuk variabel pekerjaan ibu dengan skala data nominal menggunakan $\alpha=0,05$, sedangkan untuk variabel berskala data ordinal seperti pendidikan dan pengetahuan ibu menggunakan uji Mann-Whitney. Data berskala interval seperti variabel pendapatan keluarga dan pengeluaran konsumsi menggunakan uji paramaterik dengan syarat data berdistribusi normal yaitu menggunakan Independent T-test.

\section{HASIL DAN PEMBAHASAN}

Berdasarkan hasil penelitian (tabel 1) didapatkan sebagian besar pendidikan terakhir ibu balita gizi kurang adalah tamat SMP/MTs dengan jumlah 8 orang $(42,1 \%)$. Berbeda dengan balita gizi normal, pendidikan terakhir ibu sebagian besar adalah tamat SLTA/MA dan tamat SD/MI dengan persentase masing-masing sebesar $36,8 \%$ ( 7 orang ibu). Terdapat masing-masing 1 orang $(5,3 \%)$ ibu balita gizi kurang yang tidak pernah bersekolah dan pendidikannya tamat perguruan tinggi. Pada balita gizi normal, terdapat 2 orang (10,5\%) yang tingkat pendidikan ibunya tamat perguruan tinggi.

Berdasarkan hasil uji statistik Mann-Whitney Test, didapatkan hasil nilai $\mathrm{p}=0,189$ sehingga tidak ada perbedaan tingkat pendidikan orang tua balita gizi kurang dan gizi normal. Hasil penelitian juga menunjukkan bahwa tidak ada perbedaan pengetahuan ibu pada kedua kelompok. Hal tersebut dikarenakan dalam memperoleh

Tabel 1. Distribusi Silang Status Gizi Balita berdasarkan Sosial Ekonomi dan Tingkat Pengetahuan Gizi Ibu Balita di Wilayah Kerja Puskesmas Sidotopo, Kota Surabaya Tahun 2016

\begin{tabular}{|c|c|c|c|c|c|c|}
\hline \multirow{3}{*}{ Karakteristik } & \multicolumn{4}{|c|}{ Status Gizi Balita } & \multirow{3}{*}{ Total $(n=38)$} & \multirow{3}{*}{ p value } \\
\hline & \multicolumn{2}{|c|}{ Gizi Kurang $(n=19)$} & \multicolumn{2}{|c|}{ Gizi Normal $(n=19)$} & & \\
\hline & $\mathbf{n}$ & $\%$ & $\mathbf{n}$ & $\%$ & & \\
\hline Tingkat Pendidikan & & & & & & \multirow{5}{*}{0,189} \\
\hline Tidak Sekolah & 7 & 36,8 & 7 & 36,8 & 14 & \\
\hline Tamat SMP/MTs & 8 & 42,1 & 3 & 15,8 & 11 & \\
\hline Tamat SLTA/MA & 2 & 10,5 & 7 & 36,8 & 9 & \\
\hline Tamat PT & 1 & 5,3 & 2 & 10,5 & 3 & \\
\hline \multicolumn{7}{|l|}{ Jenis Pekerjaan } \\
\hline Tidak Bekerja & 16 & 84,2 & 17 & 89,4 & 33 & \multirow{4}{*}{0,387} \\
\hline Pegawai/Karyawan Swasta & 0 & 0 & 1 & 5,3 & 1 & \\
\hline PNS/TNI/POLRI & 1 & 5,3 & 1 & 5,3 & 2 & \\
\hline Wiraswasta & 2 & 10,5 & 0 & 0 & 2 & \\
\hline \multicolumn{7}{|l|}{ Pendapatan Keluarga } \\
\hline Kuintil 1 & 4 & 21,1 & 3 & 15,8 & 7 & \multirow{5}{*}{0,189} \\
\hline Kuintil 2 & 6 & 31,6 & 3 & 15,8 & 9 & \\
\hline Kuintil 3 & 8 & 42,1 & 10 & 52,6 & 18 & \\
\hline Kuintil 4 & 1 & 5,3 & 2 & 10,5 & 3 & \\
\hline Kuintil 5 & 0 & 0 & 1 & 5,3 & 1 & \\
\hline \multicolumn{7}{|l|}{ Pengeluaran Pangan } \\
\hline Kuintil 1 & 3 & 15,8 & 2 & 10,5 & 5 & \multirow{5}{*}{0,515} \\
\hline Kuintil 2 & 2 & 10,5 & 1 & 5,3 & 3 & \\
\hline Kuintil 3 & 1 & 5,2 & 4 & 21,1 & 5 & \\
\hline Kuintil 4 & 12 & 63,2 & 8 & 42,1 & 20 & \\
\hline Kuintil 5 & 1 & 5,3 & 4 & 21,0 & 5 & \\
\hline \multicolumn{7}{|l|}{ Tingkat Pengetahuan Gizi } \\
\hline Rendah & 7 & 36,8 & 1 & 5,3 & 8 & \multirow{3}{*}{$0,004 *$} \\
\hline Sedang & 7 & 36,8 & 5 & 26,3 & 12 & \\
\hline Tinggi & 5 & 26,4 & 13 & 68,4 & 18 & \\
\hline
\end{tabular}

$* \mathrm{P}$-value $<0,05$, perbedaan signifikan 
pengetahuan tidak hanya ditentukan oleh tingginya tingkat pendidikan saja tetapi akses terhadap informasi juga perlu dipertimbangkan.

Dari penelitian ini juga diketahui bahwa ibu dari balita gizi kurang, pendidikannya cenderung lebih banyak yang hanya tamat SMP/MTs dibandingkan pendidikan ibu pada kelompok balita gizi normal. Hal ini menunjukkan bahwa ibu balita gizi kurang cenderung memiliki tingkat pendidikan yang lebih rendah dibandingkan ibu dari balita dengan gizi normal. Hal tersebut didukung oleh pernyataan Saaka (2014), bahwa ibu rumah tangga yang memiliki pendidikan rendah cenderung lebih lemah dalam mengakses informasi serta memiliki keterbatasan dalam memilih dan mengolah makanan.

Berdasarkan Tabel 1, dapat diketahui bahwa sebagian besar ibu balita baik dari balita yang berstatus gizi kurang maupun yang berstatus gizi normal adalah tidak bekerja. Sebanyak $84,2 \%$ (16 orang) ibu balita dengan gizi kurang tidak bekerja sedangkan pada kelompok gizi normal ibu balita yang tidak bekerja memiliki persentase lebih besar yaitu $89,4 \%$. Sebaliknya, persentase terkecil adalah pekerjaan karyawan swasta pada ibu balita gizi normal terdapat sebesar 5,3\% tetapi tidak ditemukan pada kelompok gizi kurang.

Hasil uji statistik chi-square menunjukkan bahwa tidak ada perbedaan jenis pekerjaan ibu antara balita gizi kurang dan gizi normal $(p=0,387)$. Hal tersebut sejalan dengan penelitian Purwaningrum (2012) yang menunjukkan bahwa jenis pekerjaan ibu pada kedua kelompok balita gizi normal dan kurang adalah sama yaitu swasta. Namun, pada penelitian ini diperoleh bahwa sebagian besar kedua kelompok balita adalah tidak bekerja.

Ibu yang tidak bekerja cenderung mempunyai lebih banyak waktu untuk mengasuh balita terutama dalam praktik pemberian makan. Pemberian makanan pada balita dapat menentukan status gizi balita, dengan pemberian makan yang baik dan sesuai kebutuhan diharapkan balita dapat tumbuh dengan sehat dan memiliki status gizi yang baik pula.

Berdasarkan Tabel 1, dapat diketahui bahwa pendapatan keluarga pada balita gizi kurang terbanyak berada pada kuintil 3 ( $>$ Rp. 1.600.000,- hingga Rp. 2.500.000,-) yaitu sebesar $42,1 \%$ sedangkan yang paling sedikit terdapat pada rentang kuintil 4 (> Rp. 2.500.000,- hingga Rp. 3.600.000,-) yaitu hanya sebesar $5,3 \%$. Pendapatan keluarga pada kelompok balita gizi normal pun tidak jauh berbeda dengan keluarga balita gizi kurang, yaitu pendapatan keluarga terbanyak berada pada kisaran kuintil 3 (> Rp. 1.600.000,- hingga Rp. 2.500.000,-) yaitu sebanyak $52,6 \%$ tetapi dengan persentase lebih besar jika dibandingkan dengan distribusi pendapatan keluarga pada kelompok balita gizi kurang. Pendapatan keluarga pada kelompok gizi kurang paling sedikit berada pada kuintil 4 dan tidak ada pendapatan yang berada pada kuintil 5 . Berbeda dengan pendapatan keluarga kelompok balita gizi kurang, keluarga kelompok balita gizi normal lebih merata pada tiap kuintil dan yang paling sedikit berada pada kuintil 5 dengan persentase sebesar 5,3\%.

Hasil uji statistik Independent t-test menunjukkan bahwa tidak ada perbedaan pendapatan keluarga antara balita gizi kurang dan gizi normal $(p=0,189)$. Hasil tersebut sejalan dengan penelitian sebelumnya yang dilakukan oleh Djola (2012) yang menunjukkan bahwa tidak terdapat hubungan antara tingkat pendapatan keluarga dengan status gizi anak balita. Hasil ini menunjukkan bahwa pendapatan bukan merupakan satu-satunya hal yang dapat mempengaruhi status gizi balita. Pendapatan yang tinggi belum tentu semuanya dibelanjakan untuk kebutuhan pangan.

Daya beli keluarga pada makanan bergizi dipengaruhi oleh pendapatan keluarga karena dalam menentukan ragam dan jenis pangan yang akan dibeli tersebut tergantung pada besar kecilnya pendapatan. Ibu yang memiliki pendapatan di samping ayah yang mencari nafkah akan lebih memudahkan keluarga tersebut memenuhi kebutuhan rumah tangganya terutama kebutuhan terhadap pangan.

Berdasarkan data pada tabel 1, dapat diketahui bahwa pengeluaran pangan pada kelompok balita gizi kurang paling banyak terdapat pada rentang kuintil 4 (Rp. 900.001,- hingga Rp. 1.500.000,-) yaitu sebesar $63,2 \%$. Begitu pula dengan kelompok 
gizi normal, persentase pengeluaran konsumsi terbesar juga terdapat pada kuintil 4 (Rp. 900.001,hingga Rp. 1.500.000,-) yaitu sebesar $42,1 \%$ tetapi jumlahnya lebih sedikit dibandingkan kelompok gizi kurang. Persentase terkecil pada kelompok balita gizi kurang ada pada kuintil 3 dan 5 sebesar masing-masing 5,3\%. Hasil uji statistik Independent T-test menunjukkan nilai signifikasi p sebesar 0,515 yang berarti bahwa tidak terdapat perbedaan pengeluaran konsumsi keluarga antara kelompok balita gizi kurang dan gizi normal.

Berdasarkan perbandingan distribusi antar kelompok, pengeluaran konsumsi untuk kuintil 4 terbesar pada kelompok balita gizi kurang dibandingkan balita gizi normal. Hal ini menunjukkan bahwa pengeluaran untuk konsumsi pada keluarga balita gizi kurang cenderung lebih besar daripada keluarga balita gizi normal. Hal tersebut dikaitkan dengan kemampuan dalam mengakses pangan. Dengan bertambahnya pengeluaran untuk konsumsi tidak selalu diikuti dengan perbaikan pola konsumsi pangan. Hal ini menunjukkan pula bahwa meskipun seseorang cenderung menghabiskan sebagian besar pendapatannya untuk konsumsi belum tentu mencerminkan bahwa apa yang dimakan tersebut sudah baik dalam mutu gizinya. Selain itu, kemampuan keluarga dalam membeli makanan tidak hanya dipengaruhi oleh besarnya pendapatan tetapi juga oleh harga bahan makanan.

Berdasarkan data hasil penelitian pada tabel 1, diketahui bahwa sebagian besar balita gizi kurang memiliki ibu dengan tingkat pengetahuan rendah $(36,8 \%)$ dan sedang $(36,8 \%)$. Sebaliknya, sebagian besar ibu balita dengan gizi normal memiliki tingkat pengetahuan yang tinggi sebesar $68,4 \%$. Angka tersebut lebih besar jika dibandingkan dengan ibu pada balita gizi kurang di mana hanya terdapat $26,4 \%$ yang berpengetahuan gizi tinggi. Persentase terendah pada kelompok balita gizi kurang adalah pengetahuan gizi ibu yang tinggi yaitu $26,4 \%$ (5 orang) sedangkan pada kelompok balita gizi normal pada tingkat pengetahuan ibu yang rendah yaitu $5,3 \%$ (1 orang).

Hasil uji statistik Mann-Whitney Test, menunjukkan nilai p sebesar 0,004 yang berarti bahwa ada perbedaan tingkat pengetahuan gizi ibu antara kelompok balita gizi kurang dan gizi normal. Hasil penelitian ini sejalan dengan penelitian oleh Indriana (2011) yang menunjukkan bahwa ada hubungan pengetahuan gizi ibu dengan kasus gizi buruk. Sesuai pula dengan pernyataan Sihadi (2006) bahwa salah satu faktor yang menyebabkan gangguan gizi adalah kurangnya pengetahuan tentang gizi dan kemampuan untuk menerapkan informasi tersebut dalam kehidupan sehari-hari karena tingkat pendidikan juga berperan dalam penyerapan informasi yang diperoleh. Namun tingginya tingkat pendidikan tidak selalu diikuti dengan tingginya tingkat pengetahuan.

Selain memiliki dampak secara langsung pada balita, pengetahuan gizi ibu juga dapat menentukan jenis dan ragam pangan yang dikonsumsi dalam keluarga. Keluarga dengan pendapatan yang tinggi belum tentu akan memilih membeli makanan yang bermutu gizi baik. Hal ini menunjukkan terdapat faktor lain yaitu pengetahuan gizi ibu yang menentukan jenis makanan yang dihidangkan dalam keluarga. Menurut Irawan (2006), ibu yang memiliki pengetahuan gizi tinggi cenderung lebih memperhatikan kebutuhan gizi balitanya sehingga dapat mengalami tumbuh kembang yang optimal dibandingkan dengan ibu yang berpengetahuan gizi rendah.

\section{KESIMPULAN DAN SARAN}

Tidak terdapat perbedaan tingkat pendidikan ibu pada balita gizi kurang dan gizi normal. Sebagian besar pendidikan ibu balita gizi kurang adalah tamat SMP/MTs, sedangkan ibu balita gizi normal hanya tamat SLTA/MA. Pekerjaan ibu balita sebagian besar adalah ibu rumah tangga dan tidak ditemukan adanya perbedaan pekerjaan ibu balita pada kedua kelompok. Selain itu, perbedaan tidak ditemukan pada pendapatan keluarga balita dan sebagian besar berada dikuintil 3. Pengeluaran konsumsi sebagian besar terdapat pada kuintil 4 di kedua kelompok balita dan tidak ditemukan perbedaan yang signifikan.

Sebagian besar pengetahuan gizi ibu balita gizi kurang adalah rendah. Sebaliknya pada balita gizi normal sebagian besar berpengetahuan tinggi. Terdapat perbedaan pengetahuan gizi ibu pada balita gizi kurang dan gizi normal. 
Diperlukan upaya meningkatkan intensitas pertemuan penyuluhan pada kelompok ibu dengan balita gizi kurang di tiap Posyandu. Penyuluhan terkait dengan materi pola pengasuhan yang baik, ASI-eksklusif, praktik pemberian makan balita (MP-ASI), dan pengolahan pangan yang beragam dilakukan dengan menggunakan media kreatif.

\section{DAFTAR PUSTAKA}

Balitbangkes Kementerian Kesehatan RI.(2013). Riset Kesehatan Dasar 2013. Jakarta, Indonesia: Author.

Black, R. E., C. G. Victora, S. P. Walker, Z. A. Bhutta, P. Christian, M. de Onis, M. Ezzati, et al. (2013). Maternal and child undernutrition and overweight in low-income and middle-income Countries. The Lancet, 382 (9890), 427-451.

Diana, F. M. (2006). Hubungan pola asuh dengan status gizi anak batita di Kecamatan Kuranji Kelurahan Pasar Ambacang Kota Padang Tahun 2004. Jurnal Kesehatan Masyarakat, 1(1), 19-23. Diakses dari http://jurnal.fkm.unand. ac.id/index.php/jkma/article/view/6

Dinas Kesehatan (Dinkes) Kota Surabaya. (2015). Hasil pemantauan status gizi balita tahun 2016. Surabaya, Indonesia: Author.

Djola, R. (2012). Hubungan antara tingkat pendapatan keluarga dan pola asuh dengan status gizi anak balita di desa Bongkudai
Kecamatan Modayag Barat. Jurnal Ilmu Kesehatan Masyarakat, 2(2), 55-60.

Irawan, R.(2006). Diagnosis gizi buruk. Jurnal Media Gizi Indonesia, 5, 337-343.

Ningsih, S., Kristiawati, Krisnana I. (2014). Hubungan perilaku ibu dengan status gizi kurang anak usia toddler. Jurnal Pediomaternal, $3(1), 58-65$.

Pelletier, DL., \&Frongillo, E.A. (2013). Changes in child survival are strongly associated with changes in malnutrition in developing countries. Journal of Nutrition, 133(1), 107-119.

Purwaningrum, S. (2012). Hubungan antara asupan makanan dan status kesadaran gizi keluarga dengan status gizi balita di wilayah kerja Puskesmas Sewon I. Jurnal Kesehatan Masyarakat, 6(3), 190-201.

Riyadi, H., Khomsan, A., Dadang, S., Faisal, A., Eddy, S. (2006). Studi tentang status gizi pada rumah tanggamiskin dan tidak miskin. Gizi Indonesia, 1. Diakses dari.http://ejournal. persagi.org/go/index.php/Gizi_Indon/article/ view/25/22

Saaka, M. (2014). Relationship between mothers' nutritional knowledge in childcare practices and the growth of children living in impoverished rural communities. Journal of Health Population Nutrition, 32(2), 237-248.

Sihadi. (2006). Kurang energi protein pada anak balita. Jurnal Epidemiologi Indonesia, 8(3). 